UDC [303.725:624.072.7]:512.547.2

Ahmad Rahbar-Ranji, Assoc.Prof.

Amirkabir University of Technology, 424 Hafez Ave., 15914 Tehran, Iran; e-mail: rahbar@aut.ac.ir

\title{
MODAL ANALYSIS OF A BOX SHAPED GIRDER BY NUMERICAL METHOD
}

Ахмад Рахбар-Ранжі. Модальний аналіз коробчастої балки за допомогою чисельних методів. Для розрахунку власних частот і форм коливань виконано модальний аналіз структур. Ці параметри є основною технічною інформацією, необхідною для аналізу і розробки будь-яких структур. Інформація про них додатково необхідна для розуміння і моделювання динамічної поведінки структур. Для прогнозування цих параметрів в простих структурах може бути використаний теоретичний підхід, однак для складних структур необхідно використовувати чисельні методи. Заявлено, що для складних структур аналітичне рішення може бути використано для прогнозування власної частоти моди першого порядку за допомогою спрощення складних структур до простих. У даній роботі проведено чисельні дослідження модального аналізу коробчастої балки, а також проведено порівняльний аналіз з моделлю двоопорної балки, яка має аналогічні характеристики поперечного перерізу. Виявлено, що за допомогою моделі двоопорної балки можна прогнозувати вібрації першого порядку, за умови адекватного врахування граничних умов.

Keywords: модальний аналіз, коробчаста балка, метод скінченних елементів.

Ahmad Rahbar-Ranji. Modal analysis of a box shaped girder by numerical method. Modal analysis of structures is carried-out to calculate natural frequencies and mode shapes. These parameters are the essential technical information required in the analysis and design of any structures. In addition, this information is needed for understanding and simulating dynamic behavior of structures. For simple structures, theoretical approach can be used to predict these parameters, however for complex structures, numerical method should be used. It is claimed that for complex structures, closed form solution can be used to predict natural frequency of first mode by idealization of complex structures to simple one. In this paper, the modal analysis of a box shaped girder is studied numerically and results are compared with simple beam model which has the same cross sectional properties. It is found that simple beam model can predict first mode of vibration, if adequate boundary conditions are considered.

Keywords: modal analysis, box shaped girder, FEM.

Introduction. Noise, malfunction and failure of mechanical systems/structures are caused by excessive dynamic behavior. Increasing demands for the condition assessment, safety and reliability assessment of structures requires needs better understanding of dynamic properties. To determine the dynamic characteristics of existing structures, modal analysis should be performed.

Modal analysis of any structure is carried-out to determine natural frequencies and mode shapes. These parameters are the essential technical information required in engineering analysis and design. For simple structures, such as beams and plates, good analytical predictions using closed form solutions can be easily found in various reference books (for example, [1]). For more complex structures, like multi-storey frames when number of degree of freedoms is limited to two or three, hand calculation still can be used for modal analysis. For higher degree of freedoms the numerical or experimental methods should be used. It is claimed that for these types of structures, simple model based on some idealization still can be used to predict the natural frequency of first mode with some acceptable accuracy.

In recent years, modal analysis has received wide acceptance in structural engineering application particularly for identification of bridges modal properties. Salane and Baldwin [2] have used the test data to determine modal stiffness and damping of single and three span bridges. Fryba and Pirner [3] have used long-term tests to determine natural frequencies and the dynamic impact factors of old bridges for the estimation of their residual life and determination of inspection intervals. Cremona [4] has used modal analysis for health monitoring of a high-speed railway bridge. Rahbar-Ranji [5] has used finite elements method (FEM) to investigate accuracy and applicability of rule-based dynamic magnification factor of a hollow box shaped girder.

Special gantry cranes are used for loading/unloading containers from ship-to-shore, which are called STS cranes. These are large dock side cranes and only seen at the container terminals. The crane 
has a boom which is extended over ship and a trolley runs along rails that are located on top of the boom. The trolley is driven by an operator sitting in a cabin suspended from the trolley. The operator runs the trolley over the ship to lift the cargos. Once the spreader latches (locks) on the container, the container is lifted and moved over the dock and placed on a truck. Boom of these cranes is in the form of space truss or hollow box shaped girders.

The aim of this work is to determine natural frequencies and mode shapes of a hollow box shaped girder using detailed FEM and to compare the results with simple beam model which has the same cross sectional properties. ANSYS computer software is used for free vibration analysis and the girder is modeled using combinations of beam and shell elements.

\section{Materials and Methods.}

Geometry of box shaped girder. The boom of a gantry crane which is used for loading/unloading of container ships is chosen for investigation. Fig. 1 shows the general dimension and arrangement of boom. The boom has $49.047 \mathrm{~m}$ length, $3.70 \mathrm{~m}$ width and $1.875 \mathrm{~m}$ height. It is composed of stiffened plate in the shape of hollow box girder (Fig. 2).

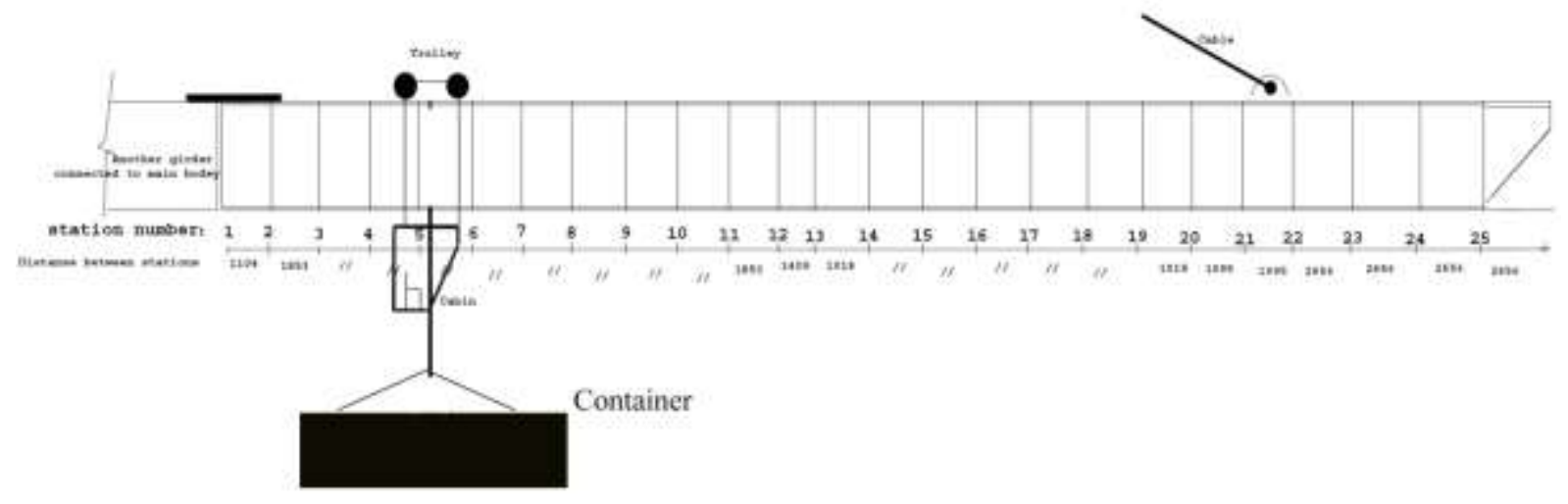

Fig, 1. Elevation view of boom girder

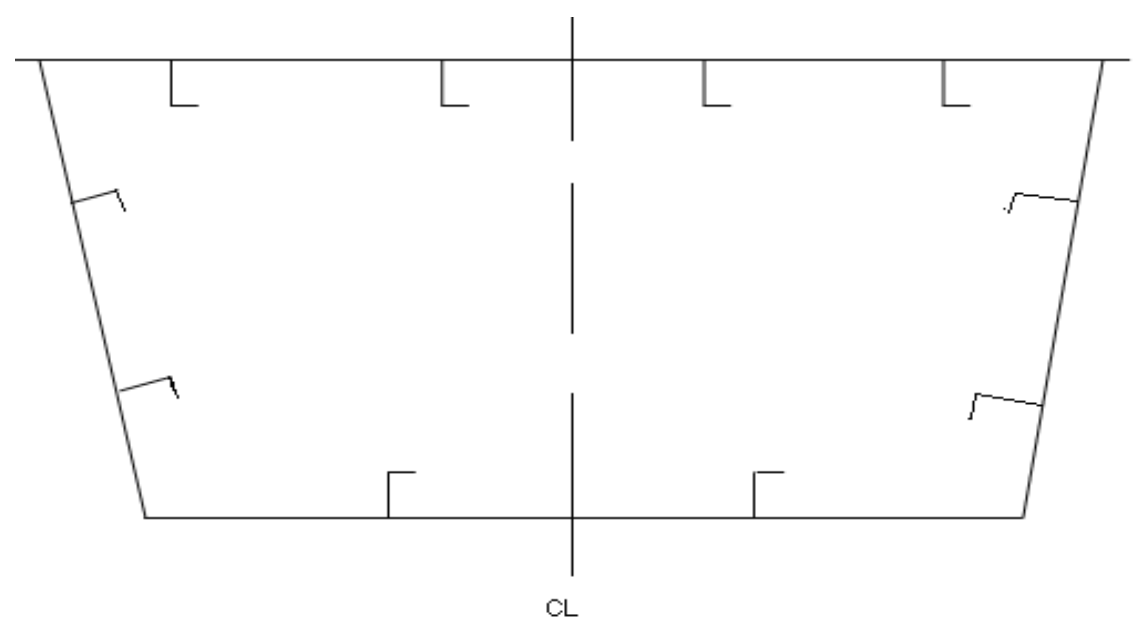

Fig. 2. Cross-section of hollow box shaped girder of boom

These plates are stiffened with longitudinal stiffeners of angle form through the full length. The boom has 26 transverse diaphragms (plates) which are placed at some intervals to prevent transverse deformation (raking). The positions of these diaphragms from one side (stations) are given in Table 1 and shown in Fig. 1. These plates have a circular or trapezoidal hole at the center which is strengthened by a ring. Thickness of plates and size of stiffeners in different parts of boom are given in the Table 2 . 
Position of Transverse Diaphragms

\begin{tabular}{c|c|c|c}
\hline Stations & $X(\mathrm{~mm})$ & Stations & $X(\mathrm{~mm})$ \\
\hline$\# 1$ & 0.00 & $\# 14$ & 22961 \\
\hline$\# 2$ & 1104 & $\# 15$ & 24879 \\
\hline$\# 3$ & 2957 & $\# 16$ & 26797 \\
\hline$\# 4$ & 4810 & $\# 17$ & 28715 \\
\hline$\# 5$ & 6663 & $\# 18$ & 30633 \\
\hline$\# 6$ & 8516 & $\# 19$ & 32551 \\
\hline$\# 7$ & 10369 & $\# 20$ & 34469 \\
\hline$\# 8$ & 12222 & $\# 21$ & 36464 \\
\hline$\# 9$ & 14075 & $\# 22$ & 38459 \\
\hline$\# 10$ & 15928 & $\# 23$ & 41115 \\
\hline$\# 11$ & 17781 & $\# 24$ & 43771 \\
\hline$\# 12$ & 19634 & $\# 25$ & 46427 \\
\hline$\# 13$ & 21043 & $\# 26$ & 49047 \\
\hline
\end{tabular}

Thickness of plates and stiffeners size

\begin{tabular}{|c|c|c|}
\hline Location & $\begin{array}{l}\text { Plate thickness } \\
(\mathrm{mm})\end{array}$ & $\begin{array}{c}\text { Stiffener size } \\
(\mathrm{mm})\end{array}$ \\
\hline Top Plate & $\begin{array}{l}10 \mathrm{~mm} \text { (from } \\
\text { station } 1 \text { to } 5 \text {, and } \\
\text { from station } 17 \text { to } \\
26 \text { ), and } 15 \mathrm{~mm} \\
\text { (from station } 5 \text { to } 17 \text { ) }\end{array}$ & $\begin{array}{c}L \\
150 \times 100 \times 10\end{array}$ \\
\hline $\begin{array}{l}\text { Bottom } \\
\text { Plate }\end{array}$ & $\begin{array}{c}10 \mathrm{~mm} \text { (from } \\
\text { station } 1 \text { to } 17, \\
\text { and from station } \\
22 \text { to } 26 \text { ) and } 15 \\
\text { mm (from station } 17 \\
\text { to } 22 \text { ) }\end{array}$ & $\begin{array}{c}L \\
150 \times 100 \times 10\end{array}$ \\
\hline Sides & 10 & $L 100 \times 50 \times 6$ \\
\hline Diaphragms & 10 , and $15 \mathrm{~mm}$ & $F B 150 \times 10$ \\
\hline
\end{tabular}

Finite elements model of Boom. The ANSYS v.10 computer software is chosen for modal analysis. First step for finite elements analysis (FEA) is to model structure adequately, which is the most laborious step of the analysis. For global vibration the plates are modeled using Shell63 plane stress elements. This four-node quadrilateral shell element is capable of modeling elastic behavior and can simulate both membrane and flexural behaviors. In addition, it has three rotational and three translational degrees of freedom per node. The stiffeners can be modeled either by beam elements or truss elements (link). If truss elements are used, the bending stiffness, which could create some errors, is ignored. However, the stiffness matrix is smaller and solution is faster. In case of very large structures, like big ships, it is necessary to use this type of elements. Beam44 beam element is used for modeling all longitudinal stiffeners and rings around circular and trapezoidal holes. BEAM44 is an uniaxial element with tension, compression, torsion and bending capabilities. The element has six degrees of freedom at each node: translations in the nodal $x, y$, and $z$ directions and rotations about the nodal $x, y$, and $z$ axes. This element allows using different unsymmetrical geometry at each end and permits offsetting of the end nodes from the centroidal axis of the beam. Fig. 3...6 show different parts of FE model of boom.

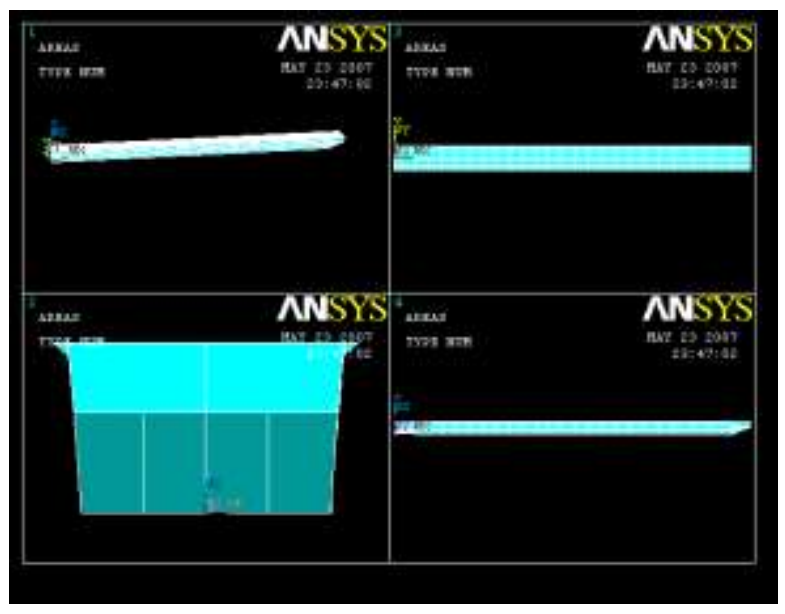

Fig. 3. Structural model of whole boom in ANSYS software

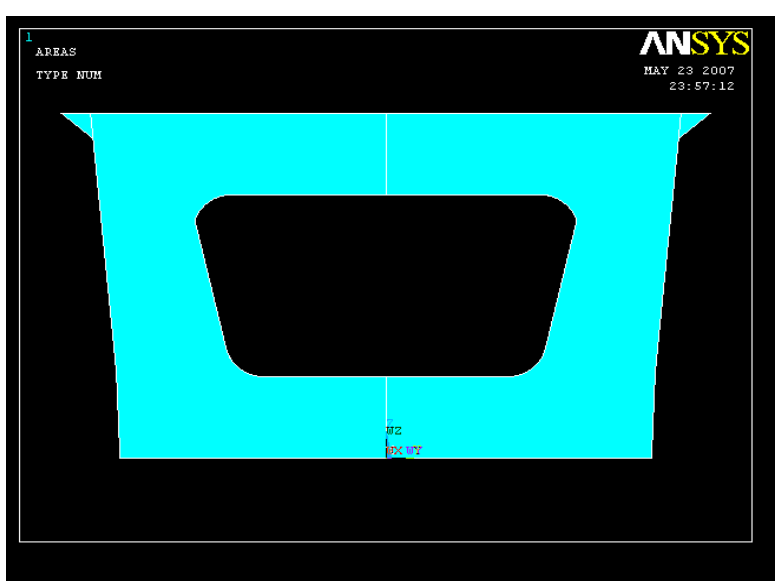

Fig. 4. Structural model of Transverse Diaphragm from station 2 to station 19 and from station 23 to station 25 


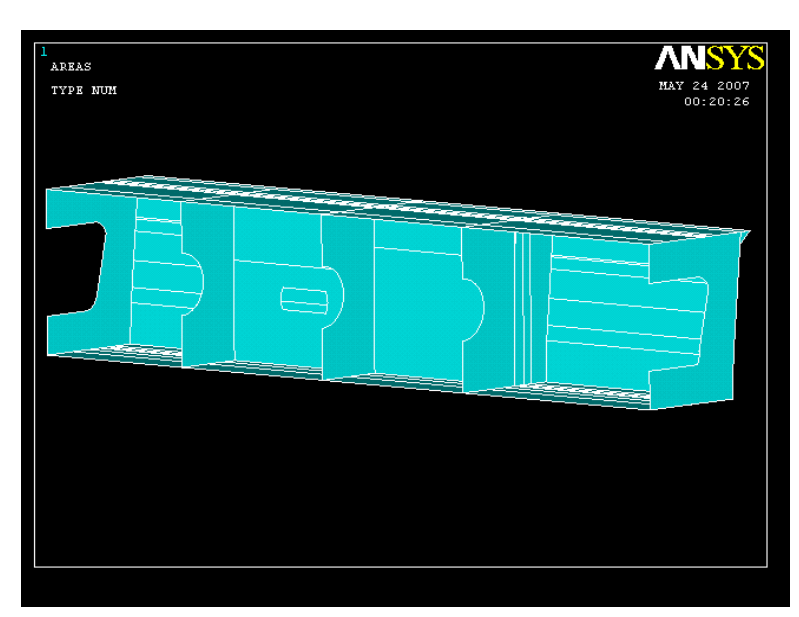

Fig. 5. Structural model of boom from station 19 to station 23

1. Boundary conditions. As it can be seen from Fig. 1, the boom is supported by sloped cables connected to eye-plates at the stations 21 to 22 , and by a plate from station 1 to 2 . Fig. 7 shows the simplified boundary condition model used for the boom. Therefore, following boundary conditions are applied (Fig. 8):

1) From station 1 to station 2 , at distance $\pm 890 \mathrm{~mm}$, and $\pm 1110 \mathrm{~mm}$ from centerline on cover-plate, $U_{x}=U_{y}=U_{z}=0$.

2) From station 21 to station 22 at distance $\pm 850 \mathrm{~mm}$, and $\pm 992.50 \mathrm{~mm}$ from centerline, on cover plate, $U_{x}=U_{y}=U_{z}=0$.

2. Masses. In the computation of vibration, the natural frequencies are highly depend on mass distribution, and following masses must be taken into account:

- boom structure,

- equipment,

- cargo (containers).

In the FE techniques, a distinction is drawn between nodal masses and element masses. For the arrangement of structural masses, as well as for the distributable parts of equipment masses, element masses are used. Here, mass of boom and rail are considered automatically by applying density for all elements $\left(7850 \mathrm{~kg} / \mathrm{m}^{3}\right.$ for structural steel).

Nodal masses are concentrated at corresponding nodal points of the FE model. This arrangement of masses is advisable for heavy parts of equipment. The total mass of trolley and container are considered as nodal mass. The trolley has 29.09 tons of weight and weight of container is considered as 50 tons. These masses are applied as concentrated masses at foot-print area of four wheels. In this study these masses are considered as $10+0.679 \mathrm{~m}$.

3. Meshing. After creating the geometry of model and applying boundary conditions and masses, the model is meshed by adequate mesh size. Fig. 9...11 show the meshed model of boom with corresponding elements. 


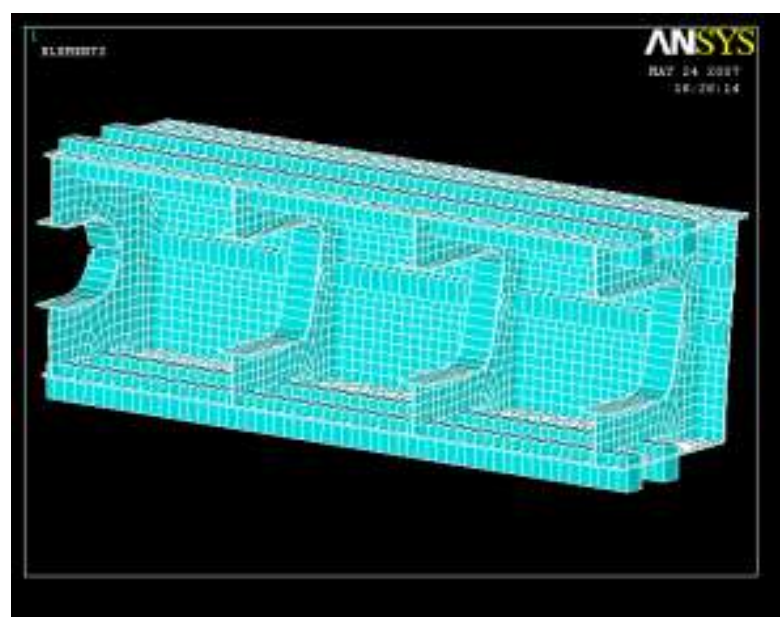

Fig. 9. Shell and beam elements of boom model from station 2 to station 5 (elements are shown by Eshape command)

\section{Results and Discussion.}

Finite Elements Model. FE computer software modal analysis is used to determine the natural frequencies and mode shapes of the boom. Modal analysis using the ANSYS products family is a linear analysis. Any nonlinearities, such as plasticity, are ignored even if they are defined. Fig. $12 \ldots 15$ show first four natural frequencies and mode shapes.

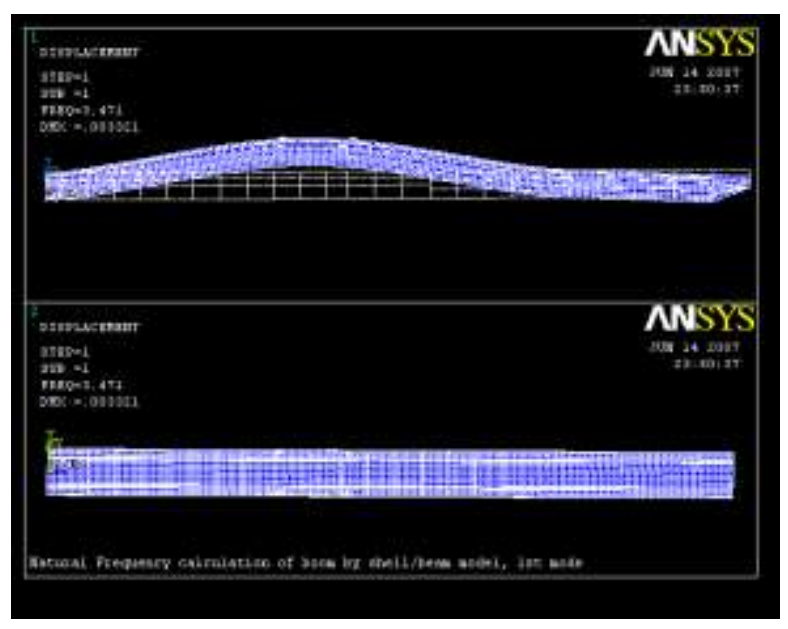

Fig. 12. Mode Shape of boom by shell/beam model, $1^{s t}$ mode

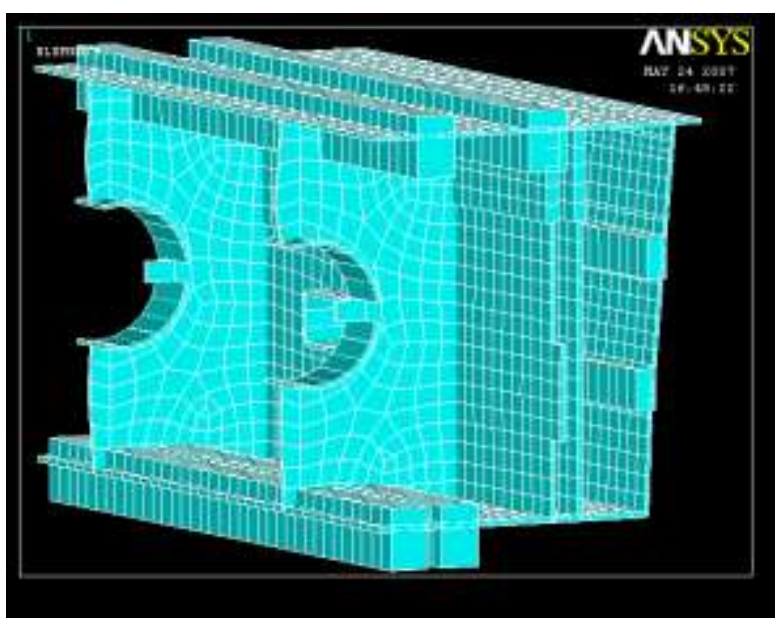

Fig. 10. Shell and beam elements of boom model from station 19 to station 20 (elements are shown by Eshape command)

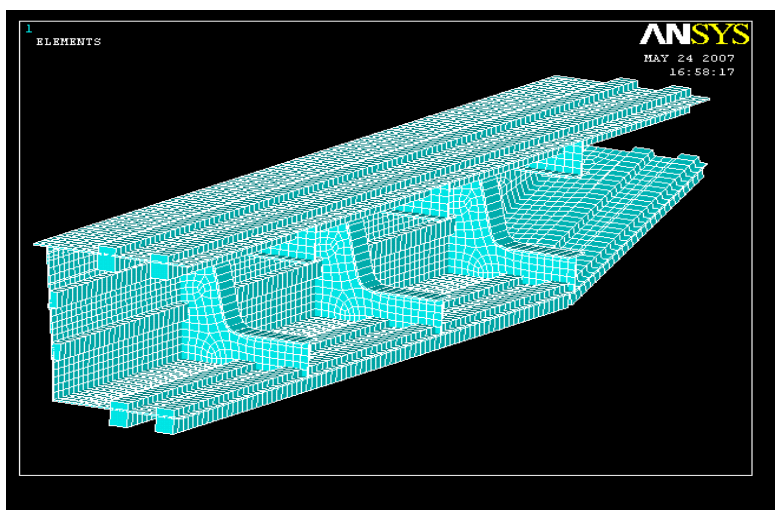

Fig. 11. Shell and beam elements of boom model from station 23 to station 26 (elements are shown by Eshape command)

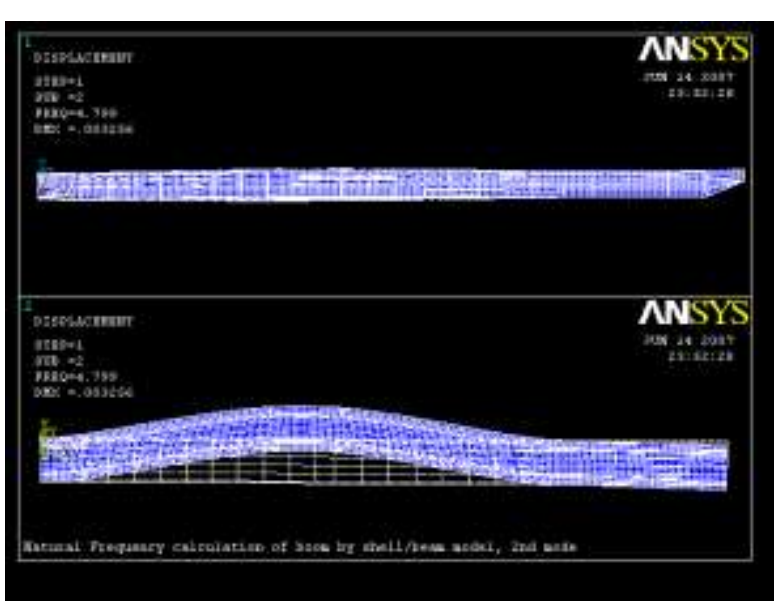

Fig. 13. Mode Shape of boom by shell/beam model, $2^{\text {nd }}$ mode 


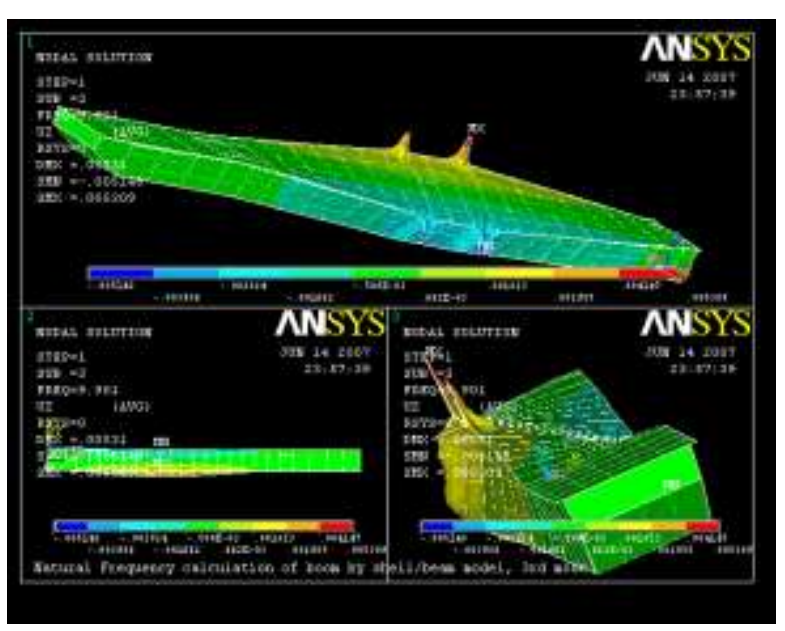

Fig. 14. Mode Shape of boom by shell/beam model, $3^{\text {rd }}$ mode

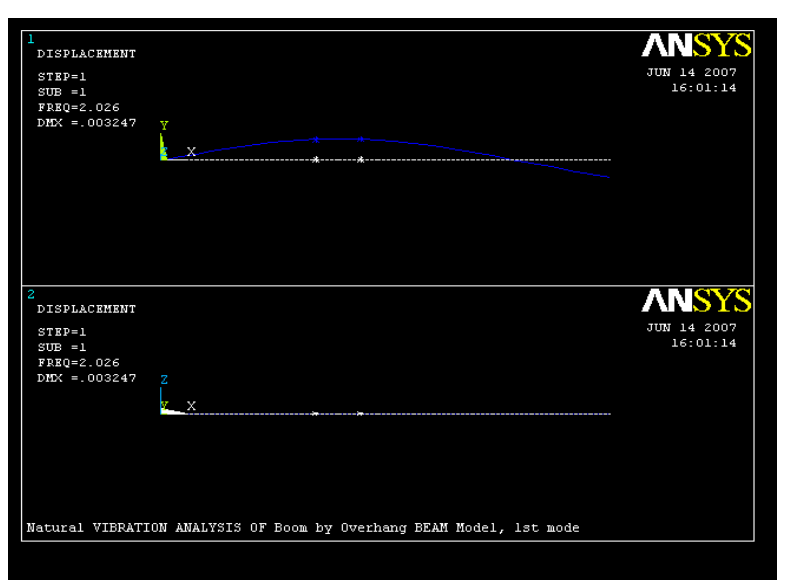

Fig. 16. Mode Shape of boom by beam model, $1^{\text {st }}$ mode

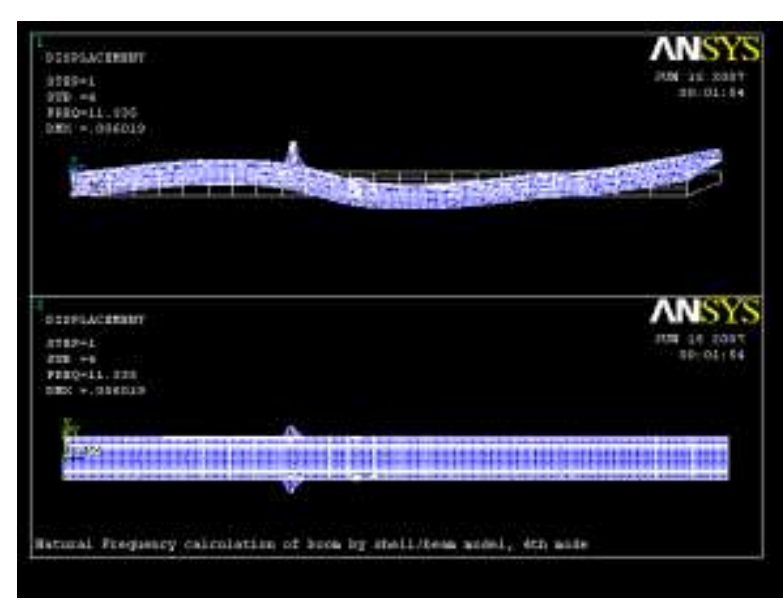

Fig. 15. Mode Shape of boom by shell/beam model, $4^{\text {th }}$ mode

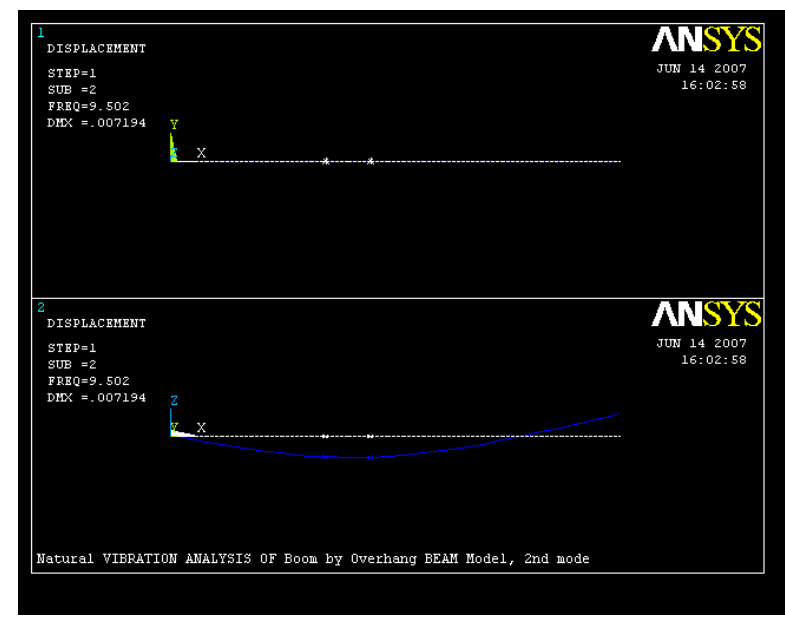

Fig.17. Mode Shape of boom by beam model, $2^{\text {nd }}$ mode

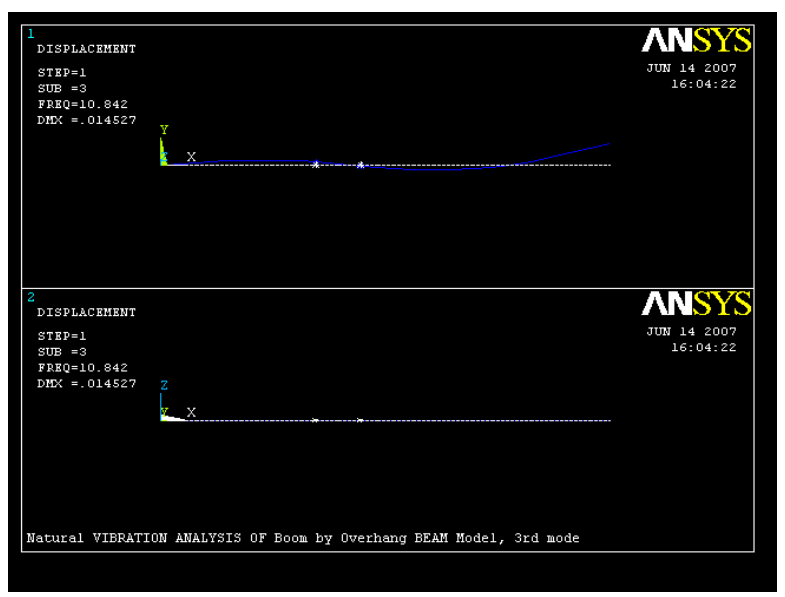

Fig. 18. Mode Shape of boom by beam model, $3^{\text {rd }}$ mode
Beam model with clamped supported boundary condition. The same beam model with clamped boundary condition at station 0.5 (Fig. 19) is considered.

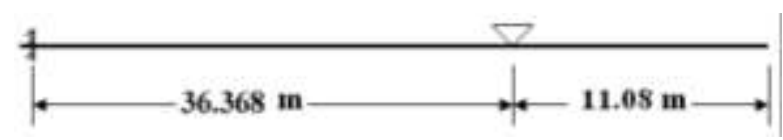

Fig. 19. Beam model with clamped boundary condition

Fig. $20 \ldots 22$ show first three vibration modes and natural frequencies of simple beam model with clamped boundary condition. 


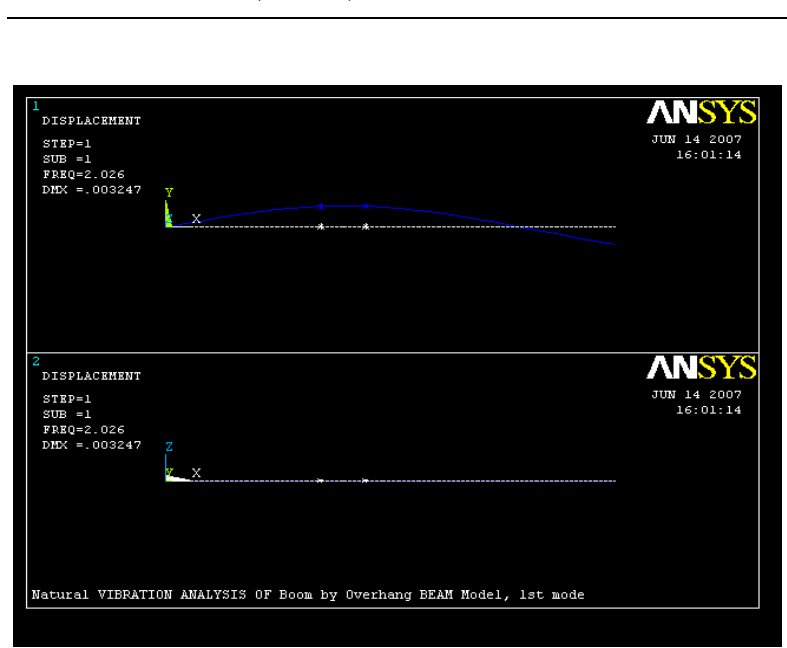

Fig. 20. Mode Shape of boom by beam model, $1^{\text {st }}$ mode

Table 3 depicts the first 10 frequencies and mode shapes of boom calculated by FEM and compared with the simple beam models.

As it can be seen, beam model with clamped boundary condition has better agreements than beam model with simple support boundary condition. The differences between beam model by clamped boundary conditions and FEM for main global vibration modes are less than $10 \ldots 15 \%$. This difference could be explained by: model,

— ignoring transverse diaphragms by beam

- applying boundary conditions in beam model at one point,

- applying mass of trolley and container in one node by beam model,

- applying boundary conditions at upper nodes in FEM having full depth in beam model.

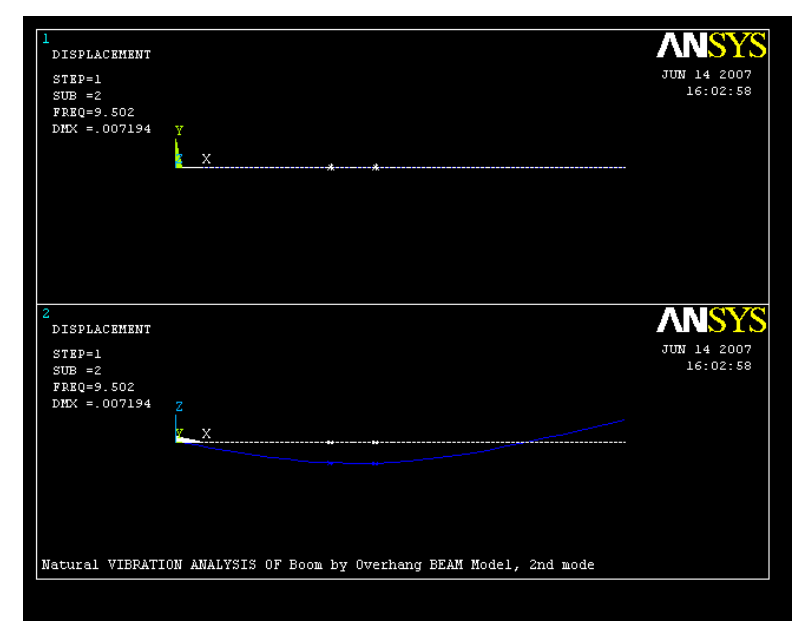

Fig. 21. Mode Shape of boom by beam model, $2^{\text {nd }}$ mode

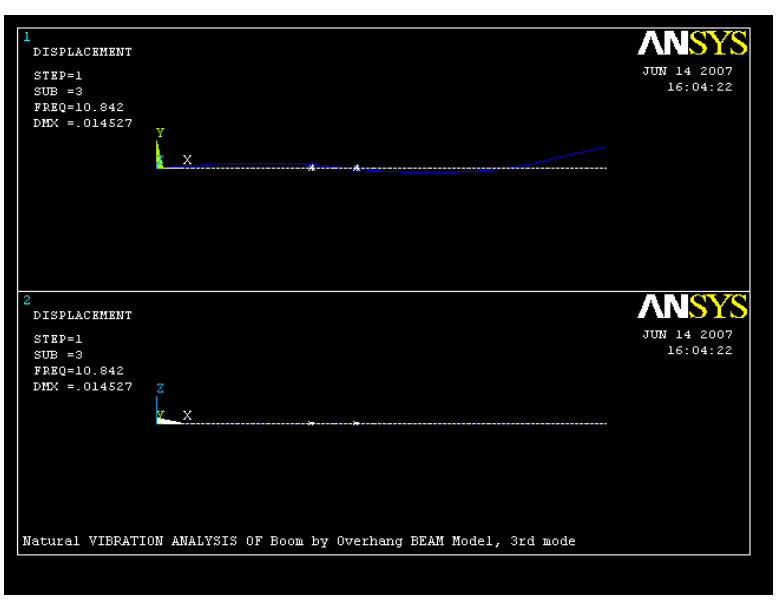

Fig. 22. Mode Shape of boom by beam model, $2^{\text {nd }}$ mode

Table 3

Summary of results for two model of boom

\begin{tabular}{c|c|c|c}
\hline \multirow{2}{*}{ Mode number } & \multicolumn{2}{|c|}{ Frequency and mode shape by beam model } & Frequency and mode shape \\
& Simply support & Clamped at station 0.5 & \begin{tabular}{c} 
beM \\
\cline { 2 - 3 } 1
\end{tabular} \\
\cline { 2 - 3 } 1 & 2.0260 & 3.0787 & 3.4714 \\
& Vertical Bending, & Vertical Bending, & Vertical Bending, \\
2 Node & 2 Node & 4.7994 \\
\hline \multirow{2}{*}{2} & 9.5022 & 9.5022 & Horizontal Bending, \\
& Horizontal Bending, & Horizontal Bending, & 2 Node \\
\hline \multirow{2}{*}{3} & 2 Node & 2 Node & 9.9006 \\
& 10.842 & 11.543 & Torsion, \\
& Vertical Bending, & Vertical Bending, & 2 Node \\
\hline
\end{tabular}




\begin{tabular}{|c|c|c|c|}
\hline \multirow{2}{*}{ Mode number } & \multicolumn{2}{|c|}{ Frequency and mode shape by beam model } & \multirow{2}{*}{$\begin{array}{c}\text { Frequency and mode shape } \\
\text { by FEM }\end{array}$} \\
\hline & Simply support & Clamped at station 0.5 & \\
\hline 4 & $\begin{array}{l}16.488 \\
\text { Longitudinal }\end{array}$ & $\begin{array}{l}16.488 \\
\text { Longitudinal }\end{array}$ & $\begin{array}{c}11.335 \\
\text { Vertical Bending, } \\
3 \text { Node } \\
\end{array}$ \\
\hline 5 & $\begin{array}{c}17.441 \\
\text { Vertical Bending, } \\
4 \text { Node }\end{array}$ & $\begin{array}{l}19.460 \\
\text { Vertical Bending, } \\
4 \text { Node }\end{array}$ & $\begin{array}{l}\qquad \begin{array}{l}12.618 \\
\text { Local Bending of cover plate }\end{array}\end{array}$ \\
\hline 6 & $\begin{array}{c}26.332 \\
\text { Horizontal Bending, } \\
\text { 3 Node } \\
\end{array}$ & $\begin{array}{c}26.332 \\
\text { Horizontal Bending, } \\
\text { 3 Node } \\
\end{array}$ & $\begin{array}{l}12.825 \\
\text { Vertical Bending of Fore Part }\end{array}$ \\
\hline 7 & $\begin{array}{c}37.028 \\
\text { Vertical Bending, } \\
5 \text { Node } \\
\end{array}$ & $\begin{array}{c}42.649 \\
-\end{array}$ & $\begin{array}{l}13.167 \\
\text { Local Bending of Cover plate }\end{array}$ \\
\hline 8 & $\begin{array}{c}42.649 \\
\text { Vertical Bending, } \\
6 \text { Node } \\
\end{array}$ & $\begin{array}{l}42.752 \\
\text { Vertical Bending, } \\
5 \text { Node } \\
\end{array}$ & $\begin{array}{l}\qquad \begin{array}{l}13.712 \\
\text { Local Bending of Cover plate }\end{array}\end{array}$ \\
\hline 9 & $\begin{array}{c}48.363 \\
-\end{array}$ & $\begin{array}{l}48.530 \\
\text { Horizontal Bending, } \\
4 \text { Node }\end{array}$ & $\begin{array}{c}14.011 \\
\text { Local Bending of Fore part }\end{array}$ \\
\hline 10 & $\begin{array}{l}48.530 \\
\text { Horizontal Bending, } 4 \text { Node }\end{array}$ & $\begin{array}{c}51.940 \\
\text { Longitudinal }\end{array}$ & $\begin{array}{c}15.901 \\
\text { Local transverse Vibration of } \\
\text { plate }\end{array}$ \\
\hline
\end{tabular}

As it could also be seen from Table 3 that order of mode shapes changes as boundary condition of beam change. For example, vertical bending mode with five nodes is seventh mode shape for beam with simple supported condition, while it is eighth mode shape in beam with clamped boundary condition. Also it can be observed that local vibration modes and torsional modes can be caught by beam model.

Conclusions. FEM is used for modal analysis of a box shaped girder. Shell elements and beam elements are used for girder modeling. Upon comparison with simple beam model, it is found that if adequate boundary conditions are chosen, simple beam model can be used to estimate some first natural frequencies of a complex structure. The local vibration and torsional vibration modes are missed using this simple model.

\section{Література}

1. Chopra, A.K. Dynamics of structures: Theory and applications to earthquake engineering / A.K. Chopra. —Englewood Cliffs: Prentice Hall, 1995. - 729 p.

2. Salane, H. Identification of modal properties of bridges / H. Salane, J. Baldwin, Jr. // Journal of Structural Engineering. - 1990. - Vol. 116, Issue 7. - PP. 2008-2021.

3. Frýba, L. Load tests and modal analysis of bridges / L. Frýba, M. Pirner // Engineering Structures. 2001. - Vol. 23, Issue 1. - PP. 102-109.

4. Cremona, C. Dynamic monitoring applied to the detection of structural modifications: A high-speed railway bridge study / C. Cremona // Progress in Structural Engineering and Materials. - 2004. Vol. 6, Issue 3. - PP. 147-161.

5. Rahbar-Ranji, A. Dynamic magnification factor in a box-shape steel girder / A. Rahbar-Ranji // Journal of The Institution of Engineers (India): Series C. — 2014. — Vol. 95, Issue 1. — PP. 11-18.

\section{References}

1. Chopra, A.K. (1995). Dynamics of Structures: Theory and Applications to Earthquake Engineering. Englewood Cliffs, N.J.: Prentice Hall.

2. Salane, H., \& Baldwin, J., Jr. (1990). Identification of modal properties of bridges. Journal of Structural Engineering, 116(7), 2008-2021. DOI:10.1061/(ASCE)0733-9445(1990)116:7(2008) 
3. Frýba, L., \& Pirner, M. (2001). Load tests and modal analysis of bridges. Engineering Structures, 23(1), 102-109. DOI:10.1016/S0141-0296(00)00026-2

4. Cremona, C. (2004). Dynamic monitoring applied to the detection of structural modifications: A highspeed railway bridge study. Progress in Structural Engineering and Materials, 6(3), 147-161. DOI:10.1002/pse. 177

5. Rahbar-Ranji, A. (2014). Dynamic magnification factor in a box-shape steel girder. Journal of The Institution of Engineers (India): Series C, 95(1), 11-18. DOI:10.1007/s40032-014-0096-2

Received June 8, 2016

Accepted July 22, 2016 